\title{
Electrochemical Properties of Graphite-based Electrodes for Redox Flow Batteries
}

\author{
Hyung Sun Kim \\ Advanced Battery Center, Korea Institute of Science and Technology (KIST), P.O. Box 131, Cheongryang, \\ Seoul 130-650,Korea.E-mail: kimhs@kist.re.kr \\ Received August 26, 2010, Accepted December 7, 2010
}

\begin{abstract}
Graphite-based electrodes were prepared using synthetic graphite (MCMB 1028) or natural graphite (NG) powder using a dimensionally stable anode (DSA) as a substrate. Their electrochemical properties were investigated in vanadiumbased electrolytes to determine how to increase the durability and improve the energy efficiency of redox flow batteries. Cyclic voltammetry (CV) was performed in the voltage range of $-0.7 \mathrm{~V}$ to $1.6 \mathrm{~V} v \mathrm{~s}$. SCE at various scan rates to analyze the vanadium redox reaction. The graphite-based electrodes showed a fast redox reaction and good reversibility in a highly concentrated acidic electrolyte. The increased electrochemical activity of the NG-based electrode for the $\mathrm{V}^{4+} / \mathrm{V}^{5+}$ redox reaction can be attributed to the increased surface concentration of functional groups from the addition of conductive material that served as a catalyst. Therefore, it is expected that this electrode can be used to increase the power density and energy density of redox flow batteries.
\end{abstract}

Key Words: Graphite-based electrode, Vanadium redox flow battery

\section{Introduction}

Redox flow batteries (RFBs) are electrochemical energy conversion and storage systems that operate through the oxidation and reduction reactions of active electrolyte materials. ${ }^{1-5}$ In recent years, there has been considerable attention on the research and development of vanadium redox flow batteries (VRBs) because of their low cost, long cycle life, deep-discharge capability, high efficiency, and low environmental impact..$^{-9}$ These batteries use the same electrodes on both sides of the cell, which are fabricated using materials such as graphite felt, activated carbon, and metal-modified carbon-felt materials. These electrodes have shown a wide potential operation range, good stability, and high reversibility as both the anode and the cathode. ${ }^{10-12}$ The standard cell potential is $1.0 \mathrm{~V}$ for the redox reaction of the $\mathrm{V}^{4+} / \mathrm{V}^{5+}$ couple at the positive electrode and $0.26 \mathrm{~V}$ for the redox reaction of the $\mathrm{V}^{2+} / \mathrm{V}^{3+}$ couple at the negative electrode. Therefore, the overall cell potential is $1.26 \mathrm{~V}$ at room temperature. As in other batteries, the electrodes are the key components of VRBs. To increase the electrochemical activity, the electrode material for RFBs should have a low bulk resistivity as well as a large specific area. The cycling performance of RFBs depends strongly on the electrochemical properties of the electrode materials. Surface modification of the electrodes has been used to enhance the electrochemical performance of RFBs. ${ }^{13-15}$ Acidic and thermal surface treatments are simple methods that can be used to improve the electrochemical activity of graphite felt electrodes. The surface functional groups of graphite electrodes can influence the electrocatalytic activity of graphite felt. Metal-modified graphite electrodes have also shown a definite beneficial effect on the redox reaction of the vanadium couple. These noble metals and their oxides have good electrical conductivity as well as stability in acidic vanadium solutions. Coating graphite felt with crystal metal is a promising method that can provide stability for the flowing electrolyte and high conductivity for the electrode. In addition, various coating methods have been employed to modify the electrode, several of which do not show sufficiently improved electrochemical activity and stability for the redox reaction. For the vanadium redox reaction, iridium(Ir)-coated carbon felt electrodes were found to exhibit excellent electrocatalytic behavior for the vanadium redox couples in sulfuric acid solution. ${ }^{15}$ In this paper, we prepared graphite-based electrodes using a dimensionally stable anode (DSA) as a substrate to increase the electrochemical stability and investigated their electrochemical characteristics in acidic vanadium electrolytes.

\section{Experimental}

Composite graphite electrodes were prepared by mixing synthetic graphite powder (MCMB 1028, Osaka Gas) or natural graphite (NG) powder (diameter: $18 \mu$ m; Sodiff Corp., Korea);, Denka Black, a carbon black conductive material (Denki Kagaku K.K., Japan); , and polytetrafluoroethylene (PTFE) binder in a wt $\%$ ratio of 90:5:5. The mixed powder was made into a paste with ethyl alcohol solvent in a bowl and formed into sheets by a rolling press. A DSA substrate was prepared using titanium mesh and $\mathrm{H}_{2} \mathrm{IrCl}_{6}$ metallic salts. The titanium mesh was pretreated with dilute hydrochloric acid at room temperature. The treated mesh was immersed in a $10 \mathrm{wt} \%$ solution of $\mathrm{H}_{2} \mathrm{IrCl}_{6}$ in ethyl alcohol solvent and dried at $80^{\circ} \mathrm{C}$ in an oven. The electrode was then treated thermally in the air at $450{ }^{\circ} \mathrm{C}$ for $15 \mathrm{~min}$ and cooled to room temperature. The immersion, drying, and heating steps were repeated five times to obtain sufficient iridium loading. The graphite sheet electrodes were assembled on the DSA substrate by roll pressing to obtain a constant thickness of 1.4 $\mathrm{mm}$. All the electrodes had the same dimensional area of $5 \mathrm{~cm}^{2}$. For electrochemical characterization, a three-electrode cell was used, it had graphite-based electrode, saturated calomel electrode, and platinum gauze electrode as the working, the reference, and the counter electrode, respectively. The electrolytes used were $2 \mathrm{M} \mathrm{VOSO}_{4}$ (Aldrich, $97 \%$ ) $+2.5 \mathrm{M} \mathrm{H}_{2} \mathrm{SO}_{4}$ and $1 \mathrm{M}$ 
$\mathrm{VOSO}_{4}+5 \mathrm{M} \mathrm{H}_{2} \mathrm{SO}_{4}$, respectively. All the electrochemical experiments were carried out at room temperature with a potentiostat/galvanostat (EG\&G 273, USA) instrument. The surfaces of the electrodes were analyzed by X-ray photoelectron spectroscopy (XPS, PHI-5800, ULVAC-PHI, Japan).

\section{Results and Discussion}

Cyclic voltammograms of the MCMB (sample 1) and NGbased (sample 2) electrodes in the $1 \mathrm{M} \mathrm{VOSO}_{4}+5 \mathrm{M} \mathrm{H}_{2} \mathrm{SO}_{4}$ electrolyte are shown in Fig. 1(A). For the MCMB-based electrode, the anodic peak at around $1.1 \mathrm{~V}$ is related to the oxidation of $\mathrm{V}^{4+}$ to $\mathrm{V}^{5+}$, whereas the cathodic peak at $0.8 \mathrm{~V}$ is associated with the subsequent reduction of $\mathrm{V}^{5+}$ to $\mathrm{V}^{4+}$. A further reduction peak of $\mathrm{V}^{4+}$ to $\mathrm{V}^{3+}$ and oxidation peak of $\mathrm{V}^{3+}$ to $\mathrm{V}^{4+}$ appear at $-0.2 \mathrm{~V}$ and $0.6 \mathrm{~V}$, respectively. The peak potential separation of $0.3 \mathrm{~V}$ for the $\mathrm{V}^{4+} / \mathrm{V}^{5+}$ redox reaction indicates that the reaction was electrochemically irreversible on the MCMB-based electrode. The cathodic reduction and anodic oxidation of the $\mathrm{V}^{3+} / \mathrm{V}^{2+}$ couple could not be observed, as they were masked by hydrogen evolution, which began at about $-0.3 \mathrm{~V}$. This phenomenon is associated with the lower hydrogen overpotential of the synthetic graphite active material on the DSA substrate. The DSA elec-

(A)

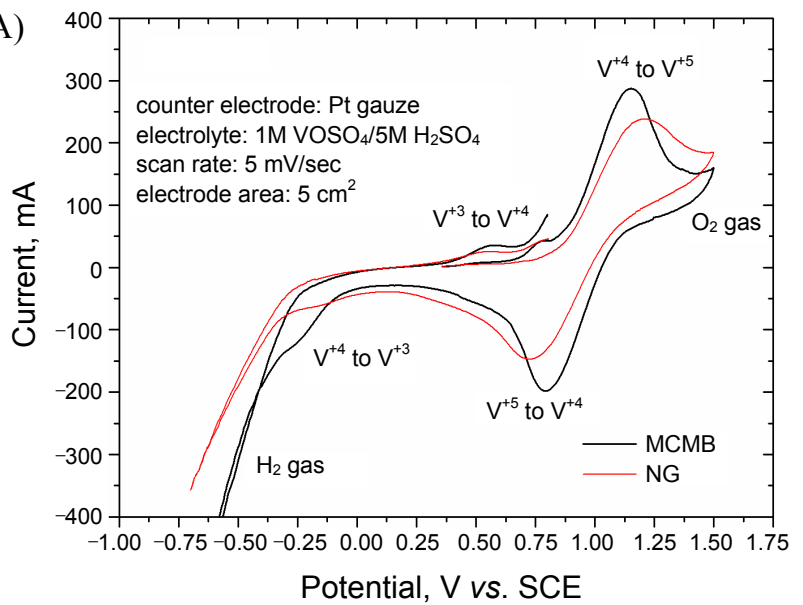

(B)

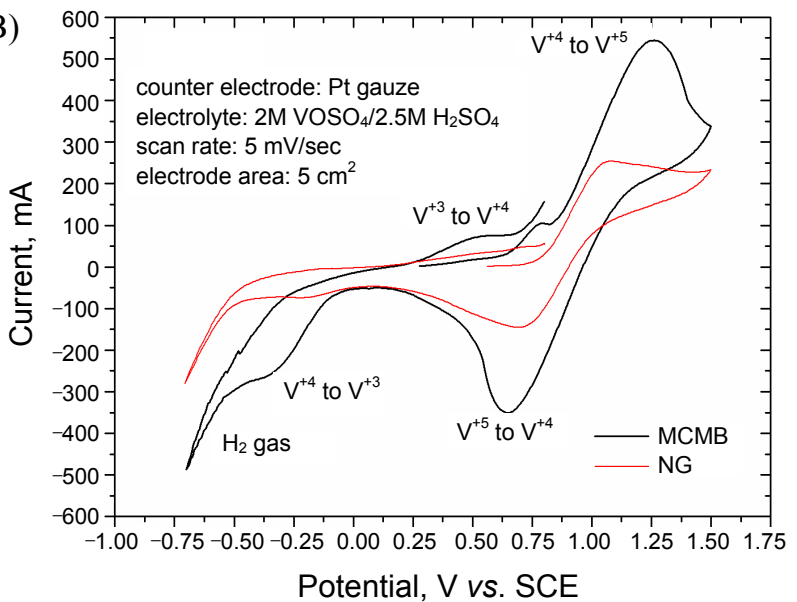

Figure 1. Cyclic voltammograms of MCMB and NG-based electrodes in $1 \mathrm{MVOSO}_{4}+5 \mathrm{M} \mathrm{H}_{2} \mathrm{SO}_{4}(\mathrm{~A})$ and $2 \mathrm{M} \mathrm{VOSO}_{4}+2.5 \mathrm{M} \mathrm{H}_{2} \mathrm{SO}_{4}(\mathrm{~B})$ electrolyte. trode was also used as the VRBs electrode and showed good stability and reversibility. ${ }^{17}$ The lower hydrogen overpotential has been reported to enhance of the electrochemical activity, but the energy efficiency of the battery decreases. ${ }^{16}$ The NGbased electrode showed more electrochemical irreversibility for the $\mathrm{V}^{4+} / \mathrm{V}^{5+}$ redox reaction and slightly higher hydrogen overpotential than the MCMB-based electrode. Neither reduction nor oxidation of the $\mathrm{V}^{3+} / \mathrm{V}^{2+}$ couple was observed on this electrode. Fig. 1(B) shows cyclic voltammograms of the same electrodes in the $2 \mathrm{M} \mathrm{VOSO}_{4}+2.5 \mathrm{M} \mathrm{H}_{2} \mathrm{SO}_{4}$ electrolyte. For the MCMB-based electrode, the anodic and cathodic peaks associated with the $\mathrm{V}^{4+} / \mathrm{V}^{5+}$ redox reaction can be observed at approximately $1.25 \mathrm{~V}$ and $0.65 \mathrm{~V}$ with a peak potential separation of $0.6 \mathrm{~V}$. This result indicates a lower electrochemical reversibility for this electrode in a highly concentrated vanadium solution compared with the results in the $1 \mathrm{M} \mathrm{VOSO}_{4}+5 \mathrm{M} \mathrm{H}_{2} \mathrm{SO}_{4}$ electrolyte. However, the peak current for the $\mathrm{V}^{4+} / \mathrm{V}^{5+}$ redox reaction increased because of the increase in vanadium ions in the acidic electrolyte. The small anodic peak at $0.8 \mathrm{~V}$ may be associated with the oxidation of other $\mathrm{V}^{4+}-\mathrm{SO}_{4}$ complex species. ${ }^{12}$ The NGbased electrode showed an almost unchanged peak current value

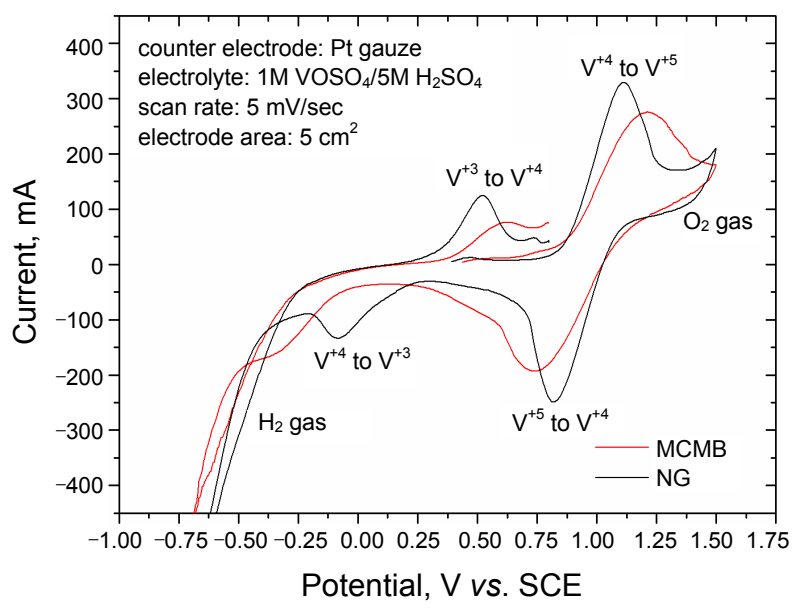

Figure 2. Cyclic voltammograms of MCMB and NG-based electrodes with conductive material in $1 \mathrm{M} \mathrm{VOSO}_{4}+5 \mathrm{M} \mathrm{H}_{2} \mathrm{SO}_{4}$ electrolyte.

Table 1. Summary of the cyclic voltammetry results in $1 \mathrm{M} \mathrm{VOSO}_{4}+$ $5 \mathrm{M} \mathrm{H}_{2} \mathrm{SO}_{4}$

\begin{tabular}{|c|c|c|c|}
\hline electrode & peak current & peak current & peak potential separation \\
\hline sample 1 & $300 \mathrm{~mA}$ & $-200 \mathrm{~mA}$ & $300 \mathrm{mV}$ \\
\hline sample 2 & $250 \mathrm{~mA}$ & $-150 \mathrm{~mA}$ & $400 \mathrm{mV}$ \\
\hline sample 3 & $300 \mathrm{~mA}$ & $-200 \mathrm{~mA}$ & $300 \mathrm{mV}$ \\
\hline sample 4 & $350 \mathrm{~mA}$ & $-270 \mathrm{~mA}$ & $200 \mathrm{mV}$ \\
\hline
\end{tabular}

Table 2. Summary of the cyclic voltammetry results in $2 \mathrm{M} \mathrm{VOSO}_{4}+$ $2.5 \mathrm{M} \mathrm{H}_{2} \mathrm{SO}_{4}$

\begin{tabular}{|c|c|c|c|}
\hline electrode & peak current & peak current & peak potential separation \\
\hline sample 1 & $550 \mathrm{~mA}$ & $-350 \mathrm{~mA}$ & $600 \mathrm{mV}$ \\
\hline sample 2 & $250 \mathrm{~mA}$ & $-150 \mathrm{~mA}$ & $400 \mathrm{mV}$ \\
\hline
\end{tabular}


(A)

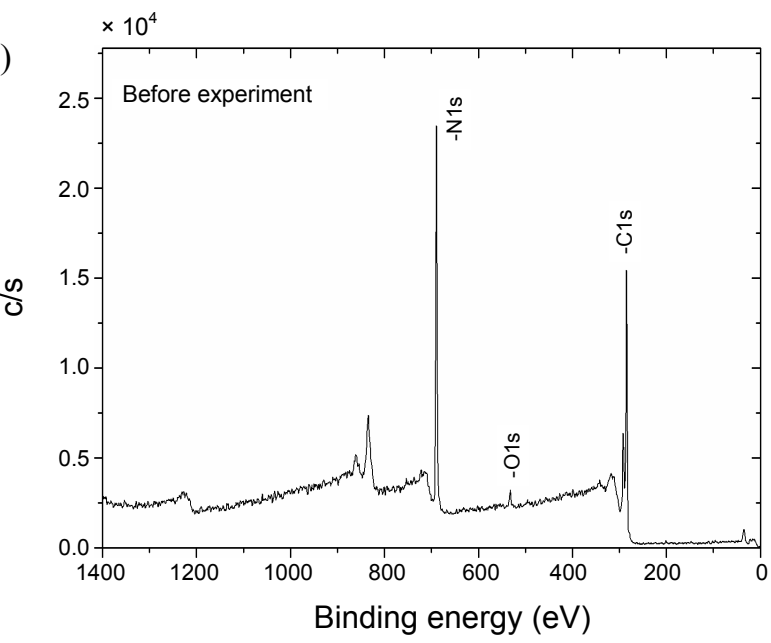

(B)

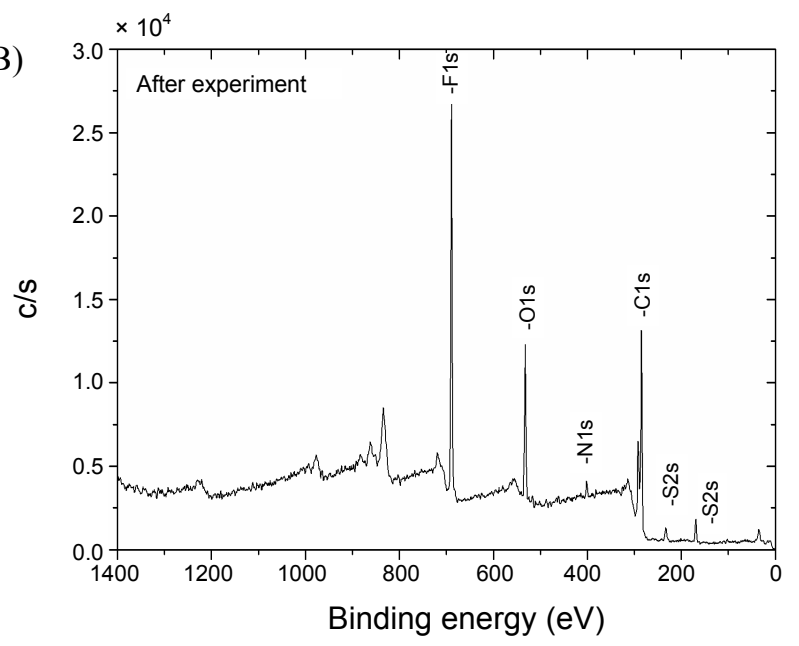

Figure 3. General XPS spectra of major elements for NG-based electrode with conductive material before (A) and after (B) experiment.

for the $\mathrm{V}^{4+} / \mathrm{V}^{5+}$ redox reaction, irrespective of the concentration of vanadium ions because of the lower electrochemical activity. Fig. 2 shows cyclic voltammograms of MCMB (sample 3) and NG-based (sample 4) electrodes containing Denka Black conductive material in the $1 \mathrm{M} \mathrm{VOSO}+5 \mathrm{M} \mathrm{H}_{2} \mathrm{SO}_{4}$ electrolyte. For the MCMB-based electrode, the peak potential and peak current for the $\mathrm{V}^{4+} / \mathrm{V}^{5+}$ redox reaction were similar to those without conductive material. On the other hand, the NG-based electrode showed a smaller peak potential separation value and higher peak current for the $\mathrm{V}^{4+} / \mathrm{V}^{5+}$ redox reaction than the MCMB-based electrode. In addition, the cathodic reduction of $\mathrm{V}^{4+}$ to $\mathrm{V}^{3+}$ and the oxidation of $\mathrm{V}^{3+}$ to $\mathrm{V}^{4+}$ could be clearly observed in the NG-based electrode containing conductive material. This is likely the result of the increased electrical conductivity of the NG-based electrode caused by the addition of conductive material. ${ }^{17}$ Typical values are summarized in Table 1 and Table 2 for the $\mathrm{V}^{4+} / \mathrm{V}^{5+}$ redox reaction in the $1 \mathrm{M} \mathrm{VOSO}_{4}+$ $5 \mathrm{M} \mathrm{H}_{2} \mathrm{SO}_{4}$ electrolyte and in the $2 \mathrm{M} \mathrm{VOSO}_{4}+2.5 \mathrm{M} \mathrm{H}_{2} \mathrm{SO}_{4}$ electrolyte.

To further understand the enhanced electrochemical activity, a general survey of major elements on the surface of the above electrodes was conducted using XPS. As shown in Figs. 3 and
(A)

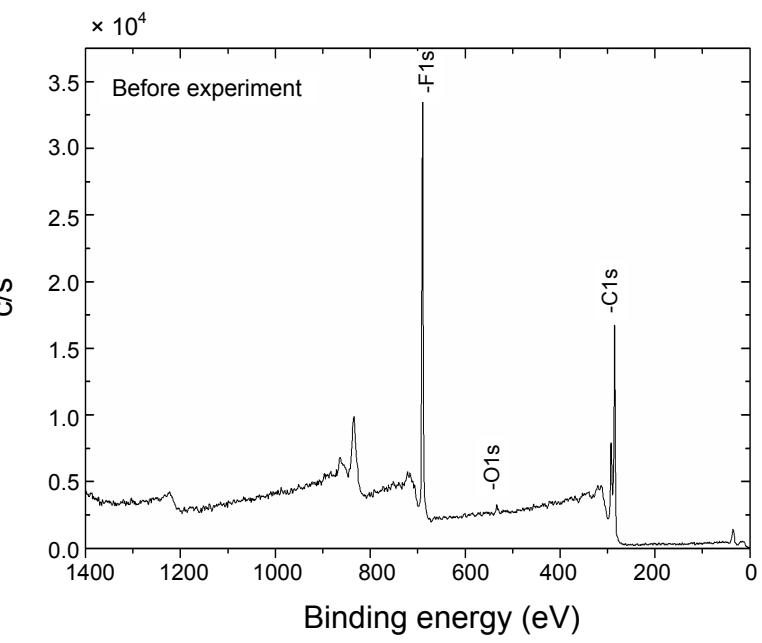

(B)

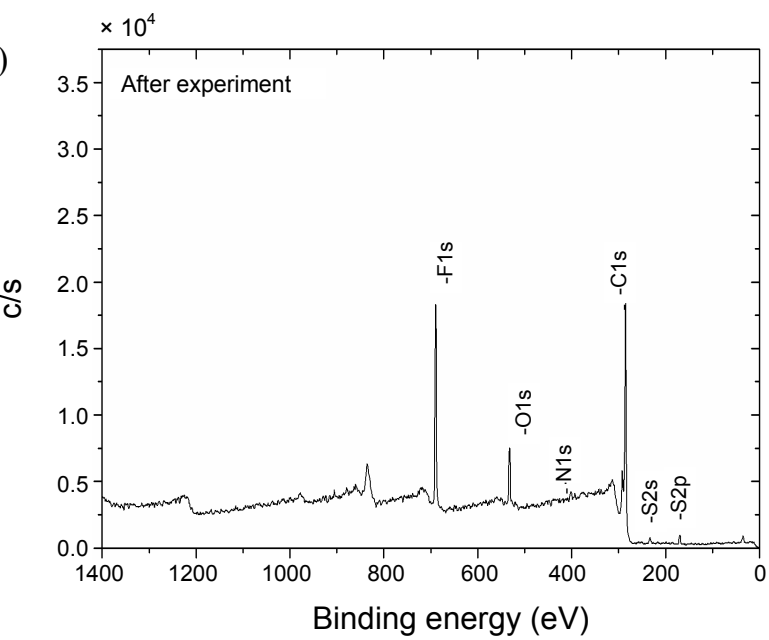

Figure 4. General XPS spectra of major elements for MCMB-based electrode with conductive material before (A) and after (B) experiment.

4, the $\mathrm{O} / \mathrm{C}$ ratio of the NG-based electrode containing conductive material increased dramatically after the experiment compared with the MCMB-based electrode. The increase in the $\mathrm{O} / \mathrm{C}$ ratio indicates an incremental increase in the $\mathrm{COOH}$ functional group during the electrochemical oxidation treatment. ${ }^{6}$ The increased electrochemical activity of the NG-based electrode for the $\mathrm{V}^{4+} / \mathrm{V}^{5+}$ redox reaction can thus be attributed to the increase in functional groups with the addition of conductive material as a catalyst. Sulfur is present on the surface as a contaminant or an adsorbed species from the electrolytes in both electrodes. Fig. 5 shows cyclic voltammograms of the MCMBbased electrodes containing conductive material in the $2 \mathrm{M}$ $\mathrm{VOSO}_{4}+2.5 \mathrm{M} \mathrm{H}_{2} \mathrm{SO}_{4}$ electrolyte. Both electrodes showed a higher peak potential separation value and peak current for the $\mathrm{V}^{4+} / \mathrm{V}^{5+}$ redox reaction than in the $1 \mathrm{M} \mathrm{VOSO}_{4}+5 \mathrm{M} \mathrm{H}_{2} \mathrm{SO}_{4}$ electrolyte. This phenomenon is associated with the balance between the electrochemical activity and the reversibility of vanadium ions in the electrolyte. The oxidation peak potential of $\mathrm{V}^{4+}$ shifts to the positive side because of the increased viscosity in the more highly concentrated sulfuric acid electrolyte. ${ }^{17}$ Apparently, the increased vanadium concentration improved the peak current for the vanadium redox reaction, but the reversibility of 


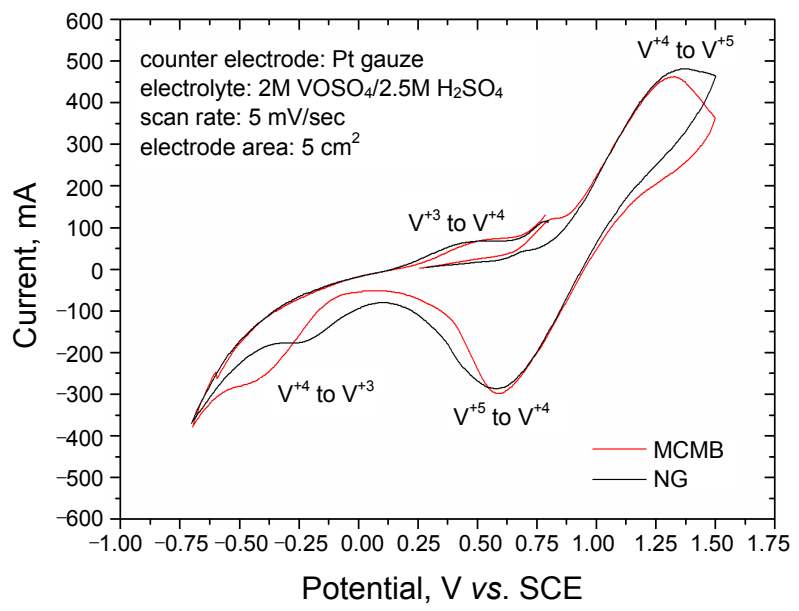

Figure 5. Cyclic voltammograms of MCMB and NG-based electrodes with conductive material in $2 \mathrm{M} \mathrm{VOSO}_{4}+2.5 \mathrm{M} \mathrm{H}_{2} \mathrm{SO}_{4}$ electrolyte.

(A)

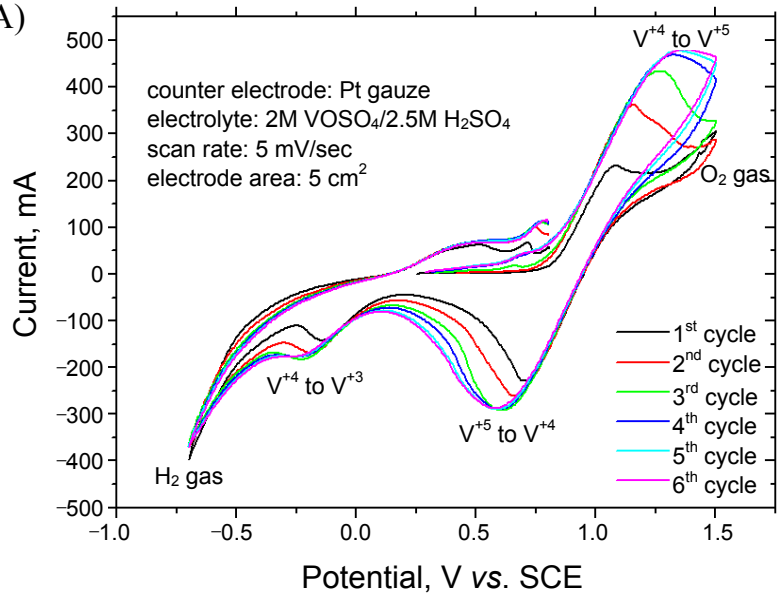

(B)

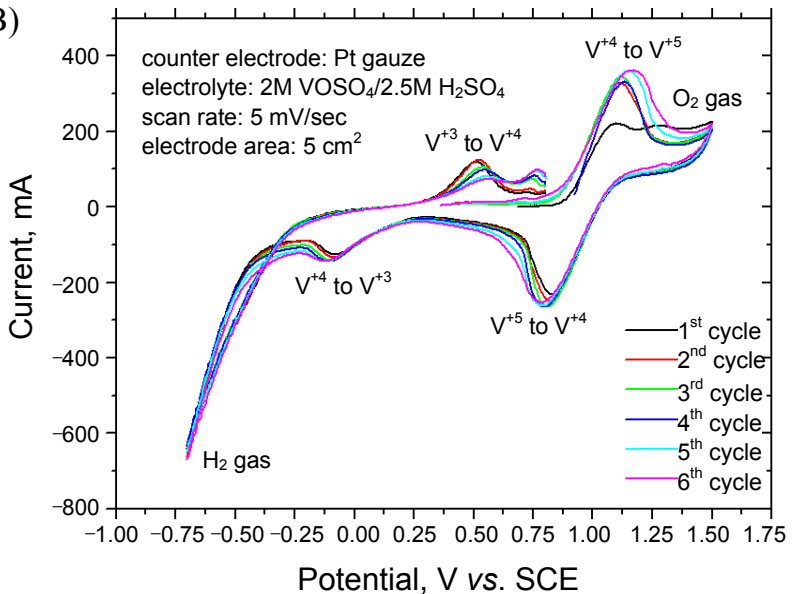

Figure 6. Cyclic voltammograms of the NG-based electrode in $2 \mathrm{M}$ $\mathrm{VOSO}_{4}+2.5 \mathrm{M} \mathrm{H}_{2} \mathrm{SO}_{4}(\mathrm{~A})$ and $1 \mathrm{M} \mathrm{VOSO}_{4}+5 \mathrm{M} \mathrm{H}_{2} \mathrm{SO}_{4}(\mathrm{~B})$ electrolyte.

the reaction decreased. Fig. 6(A) shows cyclic voltammograms of the NG-based electrode containing conductive material in the $2 \mathrm{M} \mathrm{VOSO}_{4}+2.5 \mathrm{M} \mathrm{H}_{2} \mathrm{SO}_{4}$ electrolyte after several cycles. With increasing cycle number, the peak potential separation values for the oxidation of $\mathrm{V}^{4+}$ to $\mathrm{V}^{5+}$ become more positive and

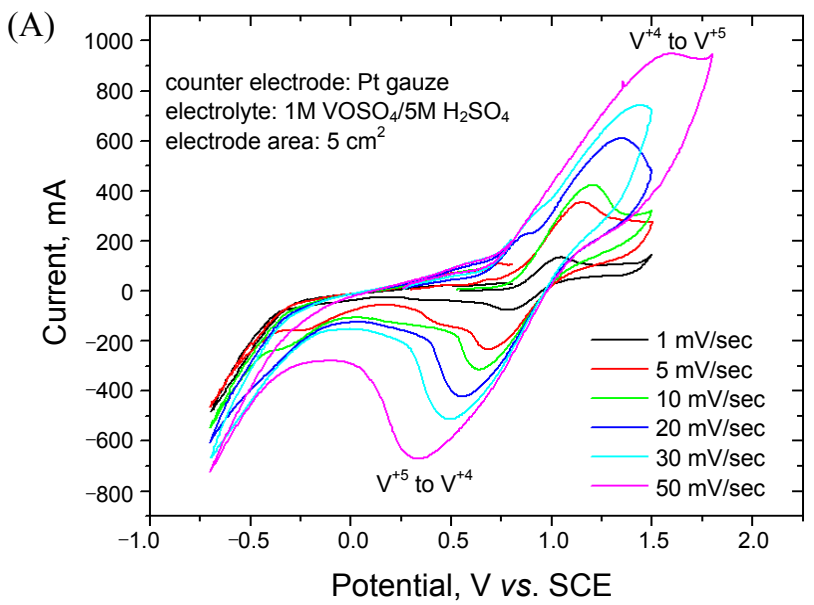

(B)

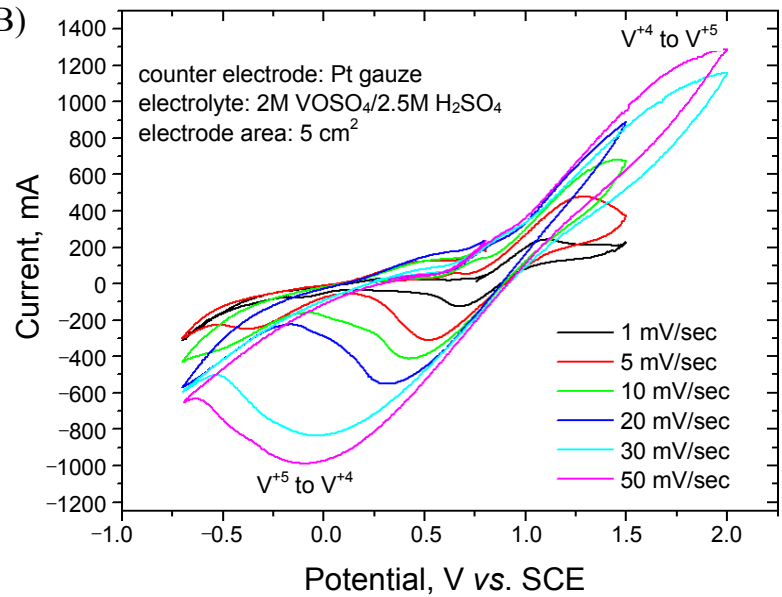

Figure 7. Cyclic voltammograms of NG-based electrode in $1 \mathrm{M}$ $\mathrm{VOSO}_{4}+5 \mathrm{M} \mathrm{H}_{2} \mathrm{SO}_{4}(\mathrm{~A})$ and $2 \mathrm{M} \mathrm{VOSO}_{4}+2.5 \mathrm{M} \mathrm{H}_{2} \mathrm{SO}_{4}$ (B) electrolytes at various scan rates.

those for the reduction of $\mathrm{V}^{5+}$ to $\mathrm{V}^{4+}$ become more negative, illustrating that the reaction on this electrode becomes more irreversible. A similar dependence of the peak potential has been reported for a graphite-reinforced carbon electrode as a function of the concentration of the electrolyte, which has been ascribed to the complex formation of $\mathrm{V}^{5+}$ and $\mathrm{V}^{4+}$ with $\mathrm{SO}_{4}{ }^{2,18}$ The redox process for the $\mathrm{V}^{5+} / \mathrm{V}^{4+}$ couple gradually changed from irreversible to quasi-reversible with increasing sulfuric acid concentration. The peak currents of the $\mathrm{V}^{4+} / \mathrm{V}^{5+}$ redox reaction also increased because of the increased wettability of the electrode and remained unchanged after the fourth cycle. Fig. 6(B) shows the cyclic voltammograms of the NG-based electrode containing conductive material in the $1 \mathrm{M} \mathrm{VOSO}_{4}+5 \mathrm{M} \mathrm{H}_{2} \mathrm{SO}_{4}$ electrolyte after several cycles. The peak potential and current for the $\mathrm{V}^{5+} / \mathrm{V}^{4+}$ redox reaction remains almost unchanged after the second cycle, indicating that the reaction was strongly electrochemically reversible on this electrode. As a result, these phenomena could apparently be influenced by the concentration of vanadium ions in the electrolyte. Fig. 7 shows cyclic voltammograms of the NG-based electrode containing conductive material in different electrolytes at various scan rates. The peak potentials for the oxidation and reduction of the $\mathrm{V}^{5+} / \mathrm{V}^{4+}$ couple remained more stable in the $1 \mathrm{M} \mathrm{VOSO}_{4}+5 \mathrm{M} \mathrm{H}_{2} \mathrm{SO}_{4}$ 
(A)

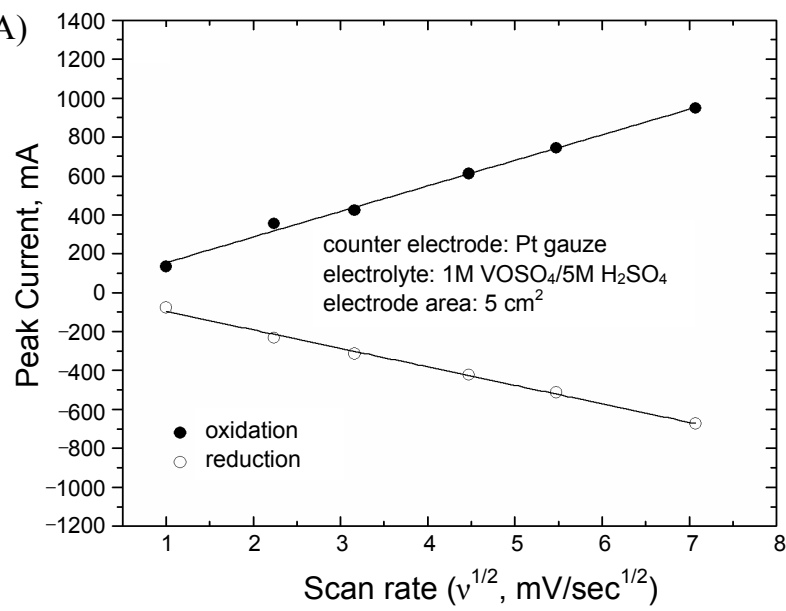

(B)

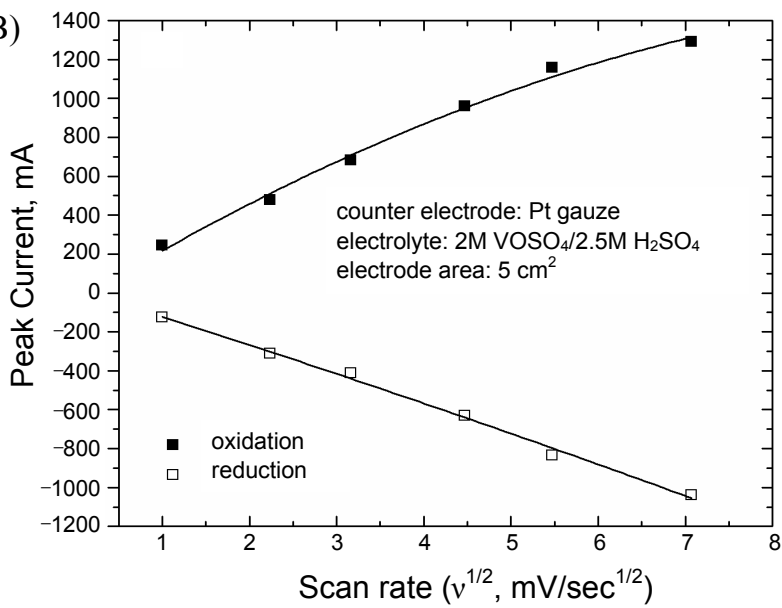

Figure 8. Peak currents as a function of the square root of the scan rates for the $\mathrm{V}^{5+} / \mathrm{V}^{4+}$ redox reaction in $1 \mathrm{MVOSO}_{4}+5 \mathrm{M} \mathrm{H}_{2} \mathrm{SO}_{4}(\mathrm{~A})$ and $2 \mathrm{M} \mathrm{VOSO}_{4}+2.5 \mathrm{M} \mathrm{H}_{2} \mathrm{SO}_{4}(\mathrm{~B})$ electrolytes.

electrolyte than in the $2 \mathrm{M} \mathrm{VOSO}_{4}+2.5 \mathrm{M} \mathrm{H}_{2} \mathrm{SO}_{4}$ electrolyte. Using the above cyclic voltammetry (CV) results, the peak currents for the oxidation and reduction of the $\mathrm{V}^{5+} / \mathrm{V}^{4+}$ couple were plotted against the square root of the scan rates, as shown in Fig. 8. The peak currents for the $\mathrm{V}^{5+} / \mathrm{V}^{4+}$ redox reactions are a linear function of the square root of the scan rates in the $1 \mathrm{M}$ $\mathrm{VOSO}_{4}+5 \mathrm{M} \mathrm{H}_{2} \mathrm{SO}_{4}$ electrolyte, indicating that the reaction was controlled by a mass transfer step. However, they are not a linear function of the square root of the scan rates in the $2 \mathrm{M}$ $\mathrm{VOSO}_{4}+2.5 \mathrm{M} \mathrm{H}_{2} \mathrm{SO}_{4}$ electrolyte, indicating that the reaction was controlled by a charge transfer step. This result suggests that the $\mathrm{V}^{5+} / \mathrm{V}^{4+}$ redox reaction on the NG-based electrode was a quasi-reversible process in the $2 \mathrm{M} \mathrm{VOSO}_{4}+2.5 \mathrm{M} \mathrm{H}_{2} \mathrm{SO}_{4}$ electrolyte.

\section{Conclusions}

Graphite-based electrodes were prepared using synthetic or natural graphite powder using a DSA substrate by roll pressing. These electrodes showed excellent redox reaction rates in vanadium-based electrolytes. The redox reaction rate of the $\mathrm{V}^{5+} / \mathrm{V}^{4+}$ couple increased as the vanadium concentration increased, but the electrochemical reversibility of the reaction decreased. The redox reaction of the $\mathrm{V}^{3+} / \mathrm{V}^{2+}$ couple was not observed in a sulfuric acid solution containing vanadium ions. The peak currents for the $\mathrm{V}^{5+} / \mathrm{V}^{4+}$ redox reaction were a linear function of the square root of the scan rates in the $1 \mathrm{M} \mathrm{VOSO}_{4}+5 \mathrm{M} \mathrm{H}_{2} \mathrm{SO}_{4}$ electrolyte, indicating that the reaction was controlled by a mass transfer step. In contrast, they were controlled by a charge transfer step in the $2 \mathrm{M} \mathrm{VOSO}_{4}+2.5 \mathrm{M} \mathrm{H}_{2} \mathrm{SO}_{4}$ electrolyte. XPS revealed that the $\mathrm{O} / \mathrm{C}$ ratio on the surface of the NG-based electrode containing conductive material increased in a concentrated sulfuric solution after cycling. This effect can be attributed to the increased electrochemical activity of the NG-based electrode in the $1 \mathrm{M} \mathrm{VOSO}_{4}+5 \mathrm{M} \mathrm{H}_{2} \mathrm{SO}_{4}$ electrolyte.

Acknowledgments. This work was supported financially by the "Energy Resources Technology Development Project" of the Ministry of Knowledge Economy in Korea.

\section{References}

1. Rydh, C. J. Power Sources 1999, 80, 21

2. Radford, G.; Cox, J.; Wills, R.; Walsh, E. J. Power Sources 2008, $185,1504$.

3. Qian, P.; Zhang, H.; Chen, J.; Wen, Y.; Luo, Q.; Liu, Z.; You, D.; Yi, B. J. Power Sources 2008, 175, 613.

4. Oriji, G.; Katayama, Y.; Miura, T. Electrochimica Acta 2004, 49, 3091.

5. Xue, F.; Wang, Y.; Wang, W.; Wang, X. Electrochimica Acta 2008, 53, 6636.

6. Huang, K.; Li, X.; Liu, S.; Tan, N.; Chen, L. Renewable Energy 2008, 33, 186.

7. Vafiadis, H.; Kazacos, M. J. Membrane Science 2006, 279, 394.

8. Chakrabati, M.; Dryfe, R.; Roberts, E. Electrochimica Acta 2007, $52,2189$.

9. Rahman, F.; Kazacos, M. J. Power Sources 2009, 189, 1212.

10. Zhu, H.; Zhang, Y.; Yue, L.; Li, W.; Li, G.; Shu, D.; Chen, H. J. Power Sources 2008, 184, 637.

11. Xhou, H.; Zhang, H.; Zhao, P.; Yi, B. Electrochimica Acta 2006, 51,6304 .

12. Sun, B.; Kazacos, M. Electrochimica Acta 1991, 36, 513.

13. Sun, B.; Kazacos, M. Electrochimica Acta 1992, 37, 2459.

14. Sun, B.; Kazacos, M. Electrochimica Acta 1992, 37, 1253

15. Wang, W.; Wang, X. Electrochimica Acta 2007, 52, 6755.

16. Conway, B.; Jerkiewicz, G. Solid State Ionics 2002, 150, 93

17. Kim, H. J. Korean Electrochemical Society 2010, 13, 123.

18. Kaneko, H.; Nozaki, K.; Aoki, T.; Negishi, A.; Kamimoto, M. Electrochimica Acta 1991, 36, 1191. 